\title{
Can Democratic Consolidation Make a Country Less Secure? The Case of Taiwan
}

\author{
Timothy S. Rich ${ }^{*}$
}

In a comparatively short time and under constant threat from the People's Republic of China (PRC), the Republic of China (ROC) on Taiwan transformed into a genuine functional democracy. Underpinning this rapid and relatively peaceful transformation to a multiparty democracy were deliberate actions taken during Taiwan's latter authoritarian days to fundamentally alter the shape democracy would take on the island. This shift has allowed for greater connections within Taiwanese society not only for the then-ruling Kuomintang (KMT) party, but for the opposition while encouraging both sides to moderate their stances regarding Taiwan's ideal relationship vis-à-vis China. The result has been a consolidated democracy mirroring Western counterparts while providing an example of a successful transition under less than ideal conditions.

While the speed of consolidation may be encouraging and certainly suggests greater internal stability, democratization has also created the potential for greater conflict with China. In an effort to curry electoral support, Taiwanese politicians often are motivated to take stances that deviate from the vague "One China" policy once respected by both sides of the strait. The lack of a unified voice on Taiwan's relations with China along with an increasing number of domestically popular but controversial reforms creates fertile ground for a misunderstanding that could lead to military conflict. Similarly, Taiwan's previous successes may lead politicians to underestimate the risk in future reforms. More generally, Taiwan's democratization has stretched the boundaries of US security commitments while potentially increasing the potential flashpoints for cross-strait conflict.

This paper will first analyze the process of Taiwan's democratization in regards to manipulation of the political space by Taiwan's political elite. From there an analysis of issue saliency and party stability suggests a level of institutionalization rare in young democracies. From there, I shift to the negative ramifications that are perhaps unique to Taiwan's path to democracy, suggesting areas of conflict which remain poorly analyzed. Through this, I hope to highlight not only the path of Taiwan's democratization, but its broader impact on crossstrait relations.

\section{Origins of Party Structures}

Scholars have long debated whether institutional or cultural effects determined party structures. Culturalists argue that historical social cleavages create party systems from the bottom up, tying parties to society and encouraging democratic stability (Lipset and Rokkan, 1967; Lijphart et al, 1993). Institutionalists counter that political elites have greater agency and that the characteristics of elite designed political structures, such as plurality versus proportional representation, shape what issues will or will not be politicized (Duverger, 1963; Zielinski, 2002). Instead of viewing these explanations as mutually exclusive, the interplay of both may provide a greater explanation of the creation and maintenance of particular party structures (Powell, 1982; Cox and Neto, 1997; Kostelecky, 2002). Although scholars who focus on this

\footnotetext{
${ }^{*}$ Timothy S. Rich is a PhD student in the Department of Political Science, Indiana University, USA.
} 
interplay primarily look at cases which were already democratic, I suggest this interaction may also be present in authoritarian regimes that wish to maintain some power while transitioning to a multiparty democracy.

Taiwan appears consistent with this combination view in that the KMT, hoping to remain competitive in the latter days of authoritarian rule attempted to alter the repressed underlying social cleavage - ethnicity-before democratization. This manipulated political space encouraged the formation of parties along a continuum based on preferences regarding Taiwan's future status. Once parties aligned on this continuum and filled the political space, the issue of Taiwan's future status quickly entrenched, aided in part by continued militant rhetoric from the Chinese mainland. The conventional wisdom accounts for political stability through crosscutting cleavages (Rae and Taylor, 1970). The move to Taiwan's future status however does not strongly crosscut ethnicity but instead aids stability by allowing both for a greater number of positions the electorate can take and greater potential for individual mobility than ethnicity. The speed of Taiwan's democratic consolidation also seems to defy much of the literature that argues that institutionalization is a long arduous process, perhaps taking decades for entrenchment (Lipset and Rokkan, 1967; Huntington, 1965; Mainwaring and Scully, 1995). Obviously each path to democracy differs, however the Taiwan case may provide insight into other democratizing states.

\section{Cleavage Transformation}

Taiwan's three main ethnic groups are the Hakka Taiwanese (14 percent of the population today), Minnan Taiwanese (70 percent) and Mainlanders who fled mainland China in the mid 1940s (14 percent). ${ }^{1}$ The imposition of Nationalist rule following Japan's surrender to the Allies in 1945 and mainland immigration to the island in the late 1940s heightened ethnic divisions. Further strengthening this division was a KMT that instead of deepening roots within Taiwanese society to legitimize their rule, chose to emphasize Taiwan's ties to China, basing their right to rule Taiwan solely in relation to its greater claim to be the legitimate government of all of China. The KMT thus remained a party essentially representing only the Mainlander minority.

The KMT only attempted democratic reforms once the ROC's international recognition began to fall behind that of the PRC, a condition worsened after the US agreed to not veto the seating of the PRC in the United Nations in 1971. Losing international recognition as the legitimate government of China undermined the ROC's already tenuous claims to internal legitimacy. Democratic reforms thus were finally in the interests of the KMT leadership.

The KMT did not however institute reforms without considering the role ethnicity would play in a democratic Taiwan. Political hopefuls in democratizing countries commonly resort to ethnic mobilization and exploit latent ethnic nationalism. Power redistribution which naturally comes with democratization also threatens stability and could have been used by the PRC as rationale for an invasion (Hsieh, 2000). In order to avoid being locked out of power if ethnic divisions emerged as the dominant mobilizing factor, KMT leaders encouraged ethnic Taiwanese to enter the party before greater political liberalization. The "Taiwanization" of the party gave the party greater roots in society, increasing its internal legitimacy which it desperately needed before democratization. Chiang Ching-kuo went as far as to choose two Taiwanese as vice presidents of the ROC, Shieh Tung-min in 1978 and Lee Teng-hui in 1984. The percentage of native Taiwanese elected to the KMT Central Committee rose from $6.1 \%$ in 1969 to $14.6 \%$ in 1976 , more than doubled by 1988 to $34.4 \%$ and was over $50 \%$ by 1998 (Huang, 1996). By instituting intraparty reform before greater democratic reforms, the KMT 
undermined the saliency of ethnic cleavages while legitimizing the KMT's right to rule Taiwan.

"Taiwanization" discouraged parties emerging on ethnic lines and instead the opposition coalesced around the only salient position not already partially co-opted by the KMT: independence for Taiwan. The KMT could thus define itself as the party of stability and reform while "Taiwanization" encouraged the KMT to seek new ways to gain votes while still the predominant party, in contrast to common perceptions of dominant parties (Wachman, 1994; Ware, 1996). By 1991, these efforts lead to both the KMT and Democratic Progressive Party (DPP) being comprised primarily of ethnic Taiwanese (Copper, 2005: 15). Party reform thus altered the political landscape before broader political reforms, allowing the KMT to remain competitive after democratization.

Figure 1: Survey Status of Taiwan

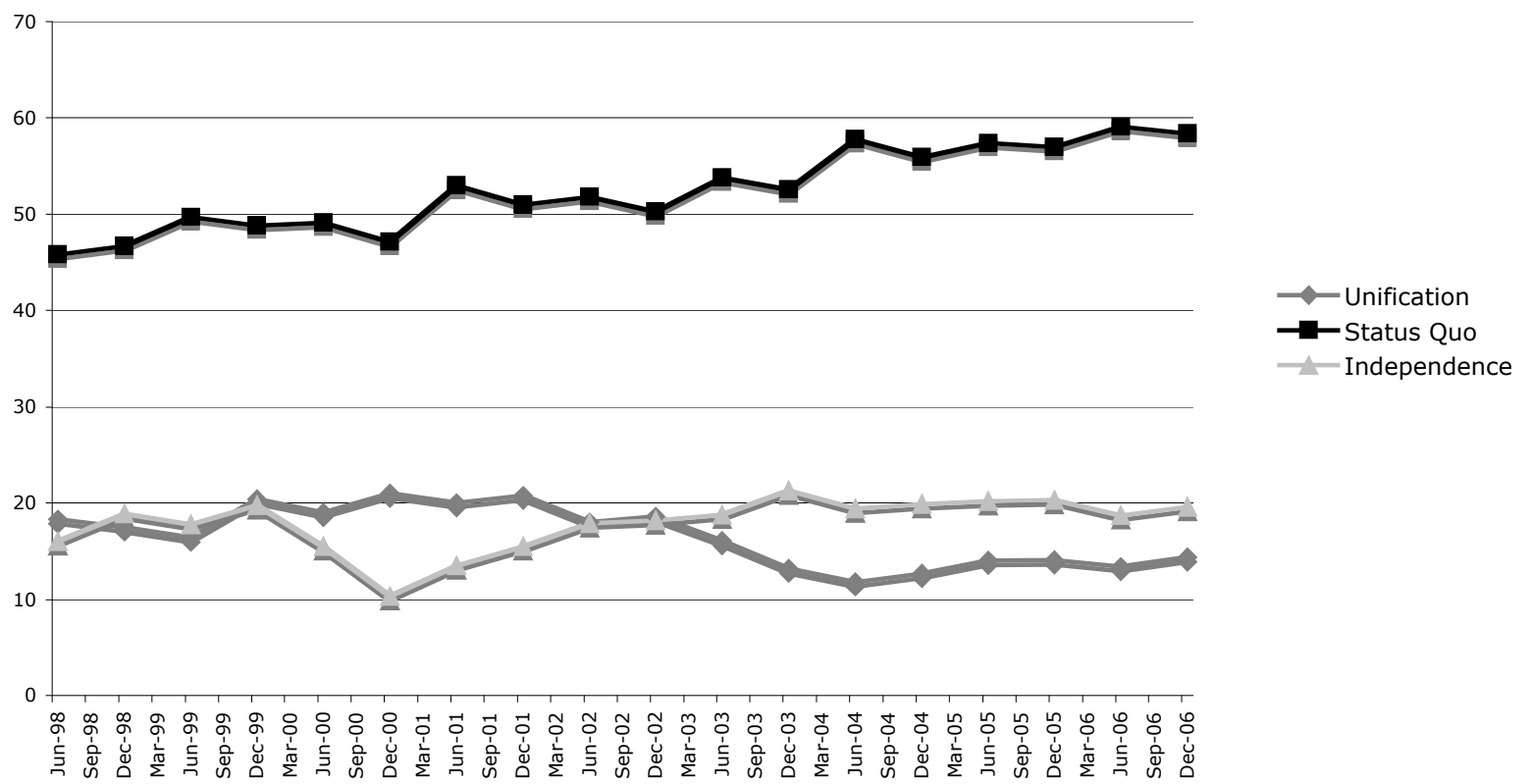

Source: Election Study Center. National Chengchi University. "Taiwan Independence vs. Unification with the Mainland Trend Distribution".

\section{Party Placement}

From the moment opposition parties were legalized, the issue of Taiwan's future status fundamentally shaped party competition. Weak party discipline coupled with Taiwan's unusual single nontransferable vote (SNTV) electoral system (abandoned only in 2008) gave incentives for party fragmentation, as seen with three splits from the KMT - the New Party (NP) in 1993, the People's First Party (PFP) in 2000, and the Taiwan Solidarity Union (TSU) in 2001. Yet despite 102 parties being registered as of June 2005 (Taiwan Yearbook), most were electorally insignificant because of an inability to find another significant political cleavage. Thus, there was no need for electoral thresholds for parliamentary representation common in newer democracies (Birch, 2001). Furthermore, by placing Taiwan's future status at the forefront, this political space allowed for both parties and voters to choose various points along the independence-unification continuum, resulting in a party system that mirrors the left-right continuum in Western democracies (Copper, 2005: 106). ${ }^{2}$ 
An analysis of Election Studies Center (ESC) data shows that the shift to this continuum has provided for a nebulously defined but stable middle ground. According to this data, since 1998, the ambiguous status quo (no preference for eventual unification or independence) is preferred by more respondents that any other option (see Figure 1). ${ }^{3}$ While support for the status quo has gradually increased over time, the average variance between surveys has been less than two percent, suggesting consistent identification. Meanwhile both the percentage of respondents supporting independence and those supporting unification have varied by less than ten percent over the entire period. Furthermore, support for the status quo varies only slightly by ethnicity. According to the 2004 Taiwan National Security Survey (TNSS) over $60 \%$ of Hakka, Minnan, and Mainlander respondents preferred the ambiguous status quo (See Table 1). The speed in which Taiwan's citizens identified with positions on this continuum is unusual, in direct conflict with Lipset and Rokkan's slow process of socialization.

Table 1: Position on Taiwan's Future by Ethnicity

\begin{tabular}{llllll}
\hline & $\begin{array}{l}\text { Unification } \\
\text { ASAP }\end{array}$ & $\begin{array}{l}\text { Status Quo Now, } \\
\text { Unification Later }\end{array}$ & $\begin{array}{l}\text { Ambiguous } \\
\text { Status Quo }\end{array}$ & $\begin{array}{l}\text { Status Quo Now, } \\
\text { Independence Later }\end{array}$ & $\begin{array}{l}\text { Independence } \\
\text { ASAP }\end{array}$ \\
\hline Hakka & $2(1.2 \%)$ & $28(17.2 \%)$ & $107(65.6 \%)$ & $24(14.7 \%)$ & $2(1.2 \%)$ \\
Minnan & $12(1.2 \%)$ & $108(11.1 \%)$ & $599(61.4 \%)$ & $193(19.8 \%)$ & $63(6.5 \%)$ \\
Mainlander & $7(4.5 \%)$ & $36(23.4 \%)$ & $98(63.6 \%)$ & $9(5.8 \%)$ & $4(2.6 \%)$ \\
\hline N & 21 & 804 & 226 & 69 \\
\hline Source: 2004 Taiwan National Security Survey
\end{tabular}

Focusing on Taiwan's future status allowed for a continuum of policy preferences versus the "us or them" nature of ethnic cleavages and parties developed fairly distinct and consistent policy stances in line with Miller et. al's criteria for institutionalized party systems (Miller et al, 2000: 460). Such ideological consistency is generally viewed as a sign of institutionalization (Mainwaring, 1998). Although the parties essentially remain committed to their founding ideologies as seen elsewhere, the manipulation of the political space to Taiwan's future status encouraged first the KMT and then the DPP to moderate their stances and move towards the status quo, consistent with the Downsian median voter theorem (Downs, 1957; Hood, 1997; Copper, 1997). ${ }^{4}$ This is despite a policy-based continuum which would presumably fit the directional model proposed by MacDonald et al. that views no benefit in taking centrist stances (MacDonald et. al, 1991)

Taiwan's party system has also broken down into two clearly defined camps, the unification-leaning pan-blue coalition (KMT/PFP/NP) and the independence-leaning pan-green (DPP/TSU), which theoretically converge at the center of the undecided status quo. Not surprisingly, identifying with one of the camps has been a strong predictor of vote intention. 2004 TNSS data shows over 96 percent of pan-blue coalition supporters and 98 percent of pan green supporters stated they voted for the coalition's presidential candidate, ${ }^{5}$ consistent with Sartori's contention on limited vote transferability (Sartori, 1976) The evidence thus suggests a remarkably stable multiparty presidential system, a possibility ignored by Mainwaring (Mainwaring, 1993). ${ }^{6}$

The Taiwanese electorate also seems exceptionally knowledgeable of the relative positions of the parties, a condition rarely present in emerging democracies (Shvetsova, 1999; Cox, 1997). Table 2 using 2004 TNSS data shows that most respondents with a party preference stated as their most disliked party one from the other camp, either the furthest away ideologically or the largest member of the coalition. The general understanding of relative party positions may explain why few electorally viable parties have emerged and how the

4 | Journal of Contemporary Eastern Asia, Volume 8, No.1 
linear political space has entrenched in line with Sartori's conception of five party competition (Sartori, 1976: 342).

Table 2: Party Preference and Least Favored Party

\begin{tabular}{llllll}
\hline Preferred & TSU & DPP & KMT & PFP & NP \\
\hline Most Disliked & NP $(70.0 \%)$ & PFP $(70.4 \%)$ & TSU $(44.1 \%)$ & DPP (48.2\%) & TSU (44.4\%) \\
& KMT $(20.0 \%)$ & KMT $(16.9 \%)$ & DPP $(41.9 \%)$ & TSU (44.7\%) & PFP (33.3\%) \\
& PFP $(10.0 \%)$ & NP $(10.2 \%)$ & PFP (9.6\%) & NP (5.3\%) & KMT $(11.1 \%)$ \\
& DPP (0\%) & TSU (2.5\%) & NP $(4.4 \%)$ & KMT (1.8\%) & DPP $(11.1 \%)$ \\
\hline $\mathbf{N}$ & 30 & 314 & 229 & 114 & 9 \\
\hline
\end{tabular}

Source: 2004 Taiwan National Security Survey

A sense of Taiwan's institutionalization can be viewed in party-society relations. Mainwaring states that institutionalized systems lead to greater voter regularity (Mainwaring, 1998: 69). To measure institutionalization in multiparty systems, parties are commonly grouped according to ideological blocs which also seems appropriate in this case (Bartolino and Mair, 1990; Kitschelt, 1995). The percentage of respondents in the ESC survey identifying with either coalition has varied by less than ten percentage points since 1998 (see Figure 2), while the average variance in each coalition's support between surveys is less than three percent $(2.5$ percent for pan-blues and 1.8 percent for pan-greens). The stability in support of both camps suggests that the frozen theory regarding parties may be applicable to Taiwan despite the SNTV system.

Figure 2: Support for Pan-Blue and Pan-Green Coalitions

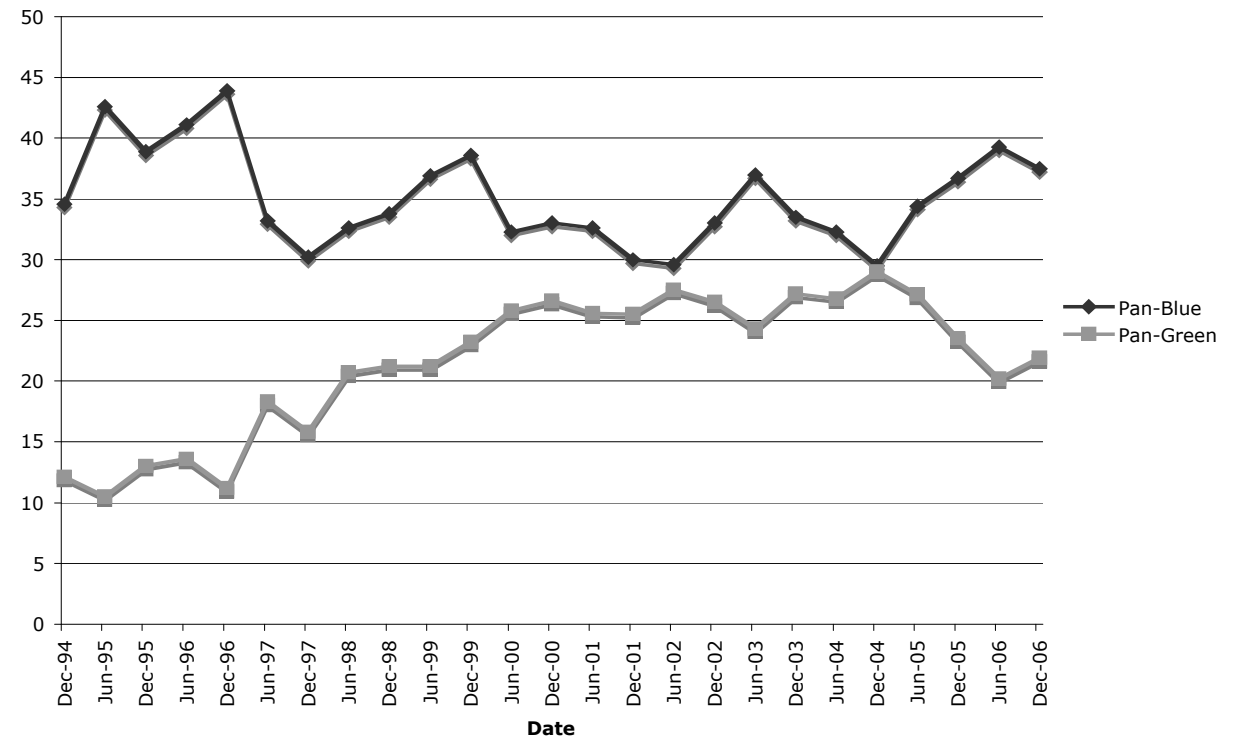

Source: Election Study Center. National Chengchi University. "Data of Party Preference Trend Distribution"

Another indicator of party stability is electoral volatility. Bartolini and Mair use electoral volatility to measure stability, arguing that decreased volatility in Western Europe substantiated Lipset and Rokkan's freezing thesis (Bartolino and Mair, 1990). Electoral volatility has also been used to gauge public satisfaction with party performance (Anderson, 1998). Traditionally party institutionalization and democratic consolidation more generally are viewed as inversely related to electoral volatility. Using the Pedersen's Index, ${ }^{7}$ Taiwan's average electoral volatility from $1995-2004$ was $13.25 \%$, in large part due to the entry of the PFP and TSU in the 2001 election (the average volatility excluding the 2001 election drops to $7.95 \%)^{8}$, 
which is comparable to other democracies. Through 1995, France, Ireland, and the Netherlands all had higher average rates of volatility, with Greece, Portugal, and Sweden, and Turkey averaging over 10\% (Anderson, 1998; Carkoglu, 1998). In contrast, new democracies in Eastern Europe and the former Soviet Union in the 1990s ranged from 13 to 47 percent (Bielasiak, 2002). Although arguably a crude measure, Taiwan's level of electoral volatility suggests a level of stability on par with if not greater than similar democracies.

\section{Consolidation}

Due to cleavage manipulation, Taiwan's politics have become more stable as both independence and unification leaning parties have moderated their stances to appeal to the proverbial median voter. Moving to the issue of Taiwan's future has also allowed for a plurality of voters to agree to at least a temporary compromise in the middle, a position difficult to reach with cleavages based on ethnicity (Dahl, 1982; Evans and Whitefield, 1998). Burgeoning democracies that maintained ethnicity as a dominant cleavage generally face great instability (Evans and Whitefield, 1998). By moving to an issue-dominated political playing field, Taiwan avoided this pitfall and remained remarkably stable throughout their process of democratization. The end result as Hsieh claims is that "ethnicity per se is no longer that salient" (Hsieh, 2005: 15).

The Taiwan example suggests that manipulation by a political elite during the initial states of democratic reforms can alter the political saliency of social cleavages and allow other factors to rise to the forefront. Once the democratic process is opened up, the parameters of this political space can quickly entrench, forcing later parties to work within the established party system while encouraging political stability. This analysis suggests that under some circumstances, authoritarian regimes without deep ties within the larger society can both democratize and endure competitive elections through intraparty reform if the latter is implemented prior to open elections.

\section{Tenuous Peace}

While Taiwan's democratization has unquestionably led to greater domestic stability, the implications of this transformation in the international sphere may not be as positive. Taiwanese officials often take actions that are domestically popular, but which alarm China. Besides controversial actions directed towards China, even Taiwan's efforts to increase their international standing are cause for concern. Taiwan's democratization and push for greater integration into the international community should theoretically increase its security, but instead reinforces China's belief that the island is moving towards independence.

The increased potential for conflict is a consequence of KMT manipulation of the political space before democratization. By promoting Taiwan's status as the dominant political issue, the KMT fundamentally altered the parameters of cross-strait relations, making each Taiwanese presidential and legislative election potentially a challenge to "One China". No longer are Taiwan's options limited to unification under either the PRC or ROC, nor can Taiwan return to only these options. As Chen Shui-bian stated, "if reunification (was) the only option, Taiwan would no longer be a democracy" (Taipei Times).

Taiwan's democratization also requires reanalyzing America's policy of strategic ambiguity. Strategic ambiguity requires a constant balancing act, but as long as all three sides adhered to a "One China" policy with the goal of eventual unification, there existed enough 
flexibility to pursue an effective dual track policy (Lasaster, 2000; Carpenter, 2006). Once Taiwan's democratic reforms implied a departure from "One China", the policy lost much of its effectiveness. Although several scholars continue to favor strategic ambiguity (Lasaster, 2000; Swaine, 2004; Nathan, 2000; Nye, 2000), one cannot ignore the flaws at the heart of this policy. Strategic ambiguity failed to prevent both Taiwan's push for greater international space and China's increased threats of force (Lasater, 2000: 305). This policy also encourages both sides to attempt to manipulate American policy while deliberately mixed signals from the US create greater confusion, both of which increase the probability of miscalculation.

While Taiwan was under authoritarian rule, the US only had to justify the defense of the island as part of a greater war against communism. Selling out Taiwan, although costly within this framework, was always possible. Democratization increased the costs of abandoning Taiwan, not only because of greater affinity for a fellow democracy among American

politicians, ${ }^{9}$ but because defending democracies from aggression has consistently been part of American foreign policy. Taiwan's actions, common to any democracy and which often knowingly and intentionally aggravate cross-strait tensions, are difficult for the US to condemn without appearing as a concession to authoritarian China. As a result, the means to maintain an effective policy of strategic ambiguity have been severely constrained.

\section{Ambiguous Actions}

Democratization altered the nature of the status quo by opening it up to various and often conflicting interpretations within Taiwanese political discourse. This lack of conceptual clarity permeates cross-strait dialogue as Taiwanese officials can define the status quo broadly to allow virtually any action, while Chinese officials can narrowly define it to exclude anything inconsistent with eventual unification. Many scholars believe that short of a formal declaration of independence, China is unlikely to attack (O'Hanlon, 2000; Swaine and Mulvenon, 2001). This however presumes that independence is an unambiguous one-step process and ignores China's fears that actions within this ill-defined status quo might have implications favoring future independence.

A few examples of presidential decisions can highlight the danger in an ill-defined status quo. Lee Teng-hui's acknowledgement of the legitimacy of the PRC on the mainland and references to a "special state to state" framework for cross-strait dialogue, while capturing political reality, implied Taiwan already has some level of de jure independence. Furthermore, Lee's framework undermined the rationale for party to party talks which the PRC favors. Similarly, Chen Shui-bian's decision to abolish the inactive Nation Unification Council (NUC) despite previous reassurances to the mainland, indicated a shift in the parameters of cross-strait dialogue that favored independence. Although none of these acts changed the political reality of cross-strait relations, Beijing immediately balked that these moves directed at the Taiwanese public were steps towards independence.

Even what may appear as minor constitutional reforms have broad implications. Reforming a constitution drafted in 1947 before the KMT fled the mainland to meet the requirements of a vibrant democracy is necessary but nevertheless controversial. Reforms to allow for Taiwan's first referendum set a precedent that may allow for a future referendum on Taiwan's status, a situation Chinese leaders adamantly oppose as it would suggest independence as a legitimate option. Lin argues that Taiwan's referendum structure actually adds more veto-playing forces and raises the cost of changing the status quo (Lin, 2004); however this 
does not negate the symbolic effect the mere establishment of a referendum law has on crossstrait relations.

Furthermore, Taiwan's democratization and a need to distinguish itself from China has led politicians to promote the terms "Taiwan" and "Taiwanese" over "China" and "Chinese". Although adding the word "Taiwan" to passports and changing the name of buildings and government-owned companies has practical purposes, it also suggests an incremental strategy towards independence. More importantly, even if unification leaning politicians wanted to reverse these changes in the future (as evident since Ma Ying-jeou's election), it would be difficult to garner public support for an action that seems to appease China. Democratization made Taiwan more internally stable, but also made changes effecting cross-strait relations inevitable.

While Taiwanese officials have been more willing to push the parameters of the status quo, the Chinese side may have become less tolerant as evident in the 2005 anti-succession law. Vagueness on what constitutes their threshold allows China to frame Taiwan's unclear actions as independence-oriented while statements regarding their willingness to respond with force attempts to reduce any misconceptions about Chinese resolve on unification. Furthermore, China's apparent willingness to use force when Taiwan's actions are unclear appears consistent with China's past uses of force to slow or reverse trends believed to be against their interests (Garver, 1997: 62; Wu, 2001: 66-67; Shih, 2003: 25; Pollack, 1996). Recent military improvements may also encourage China to act more unilaterally than before (Christensen, 2001; Van Kemenade, 2000). Although changes on Taiwan's side are primarily geared towards a domestic audience, these changes may signal that time is running out for China's preferred solution to come to fruition, thus encouraging a more hardline and counterproductive Chinese response.

\section{International Presence}

Since democratization, and urged on by a populace that viewed Taiwan's role in international relations declining, the ROC has increased efforts to improve its international presence. Greater attention has been placed on increasing formal diplomatic recognition and joining international organizations (most notably the United Nations). These efforts however, besides consistently aggravating the PRC, have done little to promote cross-strait stability and may actually give incentives to prolong tension between the two sides.

Once recognized by the majority of countries, the ROC now has formal relations with only 23 countries compared to 169 recognizing the PRC, which leaves them more diplomatically isolated than Apartheid-era South Africa (See Table 3). ${ }^{10}$ To promote formal recognition, Taiwan has framed recognition as respect for democratic values and several countries have reiterated such a rationale for relations with the ROC (Peterson, 1997). However, democratization only seems to have strengthened existing diplomatic relations.

The instability of the Taiwan's recognition is apparent when seeing how many countries have switched recognition. The most egregious examples, Senegal and Central African Republic, have switched five times since both originally forging diplomatic ties with the ROC in 1962. Ten other countries-Benin, Burkina Faso, Chad, the Gambia, Lesotho, Liberia, Nauru, Nicaragua, Niger, and St. Lucia - switched diplomatic recognition more than once, eight of them at least once in the last fifteen years. Switching between the ROC and PRC has also occurred in relations with Central American, Caribbean and Pacific Island countries, undermining the stability generally associated with the granting of diplomatic recognition. 
Table 3: Countries Recognizing the ROC (date recognition was last established)

\begin{tabular}{ll}
\hline Belize (1989) & Nicaragua (1990) \\
Burkina Faso (1994) & Palau (1999) \\
Dominican Republic (1957) & Panama (1954) \\
El Salvador (1961) & Paraguay (1957) \\
Gambia (1995) & Sao Tome and Principe (1997) \\
Guatemala (1960) & Solomon Islands (1983) \\
Haiti (1956) & St. Kitts and Nevis (1983) \\
Holy See (1942) & St. Lucia (2007) \\
Honduras (1965) & St. Vincent and the Grenadines (1981) \\
Kiribati (2003) & Swaziland (1968) \\
Marshall Islands (1998) & Tuvalu (1979) \\
Nauru (2005) & \\
\hline
\end{tabular}

Source: Ministry of Foreign Affairs, Taipei.

Unlike traditional diplomatic relations, Taiwan's recognition is often conferred in connection to large aid packages and is referred to as "dollar diplomacy". Although prevalent for decades, the connection between aid and recognition has become more explicit since democratization and has been further exacerbated by the PRC also willing to play the same game (Payne and Veney, 2002: 116; Rawnsley, 2000: 32; Wang, 2001: 732). Linking aid to recognition invites trouble as it attracts governments looking for quick fixes to their own economic problems. ${ }^{11}$ "Dollar diplomacy" arguably prevented the ROC from losing further recognition, but is losing its effectiveness now that the PRC is also willing to tie aid to recognition. Many countries appear to ratchet up the demands and merely go with the highest bidder when current tensions benefit them and thus have little reason to develop deeper ties to either side. Furthermore, each country that switches recognition simply frees up more money for the losing side to woo another country, creating a vicious cycle of diplomatic competition.

Table 4: Countries That Supported the UN Petition to Seat the ROC*

\begin{tabular}{lll}
\hline Year & Countries Supporting & Diplomatic Allies \\
\hline $\mathbf{2 0 0 1}$ & 10 & 29 \\
$\mathbf{2 0 0 2}$ & 12 & 28 \\
$\mathbf{2 0 0 3}$ & 16 & 27 \\
$\mathbf{2 0 0 4}$ & 15 & 27 \\
$\mathbf{2 0 0 5}$ & 11 & 26 \\
$\mathbf{2 0 0 6}$ & 16 & 25 \\
$\mathbf{2 0 0 7}$ & 15 & 24 \\
\hline
\end{tabular}

Source: Ministry of Foreign Affairs website and United Nations website

*Denotes peak number of countries recognizing the ROC in that year.

It is also unclear what tangible benefits Taiwan receives from formal recognition. Those recognizing the ROC are all minor players in international relations, providing no deterrence from a Chinese attack, and whose primary means of influence in world affairs is their vote in the UN General Assembly. Even this has not greatly benefited Taiwan. Since 1993 the ROC has used its few allies to annually support re-entry into the UN; however many of them have not supported these petitions. In 1997, only 15 of 26 diplomatic allies spoke in favor of the ROC's bid, while 31 non-recognizing states spoke in opposition (Central News Agency; Rawnsley, 2000: 32). Since 2001, only about half of the countries recognizing the ROC have actually supported the yearly proposal (See Table 4). With Chinese threats to block future 
UN assistance to countries supporting Taiwan's bid, the lack of support among ROC diplomatic allies should not be surprising. At best the UN push is symbolic, a signal to the Taiwanese electorate that the ROC will continue to push for international recognition.

Although efforts to promote Taiwan's standing are domestically popular and blunt China's claims to sovereignty, these efforts have serious repercussions. Efforts at formal recognition and membership in international organizations where statehood is a requisite persuades China to take a harsher stance. China has increasingly pushed recognizing countries to declare support for their interpretation of "One China" where the issue was previously often left ambiguous. By attempting to integrate itself into the global community as a separate entity, Taiwan indirectly may be encouraging a restriction of its international space.

Taiwan's efforts in part intend to build international support for the island if Beijing attacks, but any gains from this strategy may be outweighed by a more hostile China. The island's unofficial relations, especially with the US, will prove more of a deterrent than official relations with smaller powers ever will. Taking unofficial diplomatic relations into consideration, Taiwan's international presence is greater than any other time since 1979 and continues to increase. Despite continued switching of diplomatic recognition, Taiwan's formal recognition has largely stabilized around 25 diplomatic allies, while unofficial relations have been established with virtually every major country since Taiwan's democratization. The island's democratic consolidation has been applauded by recognizing and non-recognizing countries alike while Taiwan's vibrant economy has been seen as a model for many developing nations (including perhaps China). In fact, Taiwan's democratization could be viewed as the primary factor leading most countries to just pay lip service to Beijing's "One China" model (Cabestan, 1998: 239). Thus it becomes difficult to comprehend that Taiwan's position in international affairs will be extinguished unless it intentionally tries to butt heads with the mainland.

\section{Conclusion}

The case of Taiwan suggests that elite-driven reforms can assist in democratic consolidation. Through a combination of intraparty reform and cleavage manipulation, the KMT repositioned itself to remain electorally competitive once opposition parties were allowed. This analysis shows that decisions made by the political elite helped produce a stable multiparty system by transforming the political space away from ethnic cleavages and towards a policy continuum more conducive to developing a middle ground. The transformation to a policy continuum based on Taiwan's status vis-à-vis China however creates greater potential for cross-strait conflict as Taiwanese leaders negotiate the two-level game of appealing to Taiwanese voters while, intentionally or not, sending distressing signals to China.

Democratization usually promotes peace through greater transparency. While domestically this is true for Taiwan, democratization also magnified Taiwan's precarious international status. Taiwan's efforts to exert a greater role in international affairs would otherwise not be noteworthy except that China continues to see the diplomatic arena as a zero sum game, implying that the PRC losing diplomatic recognition even from a tiny nation such as Kiribati strengthens Taiwan's ability to avoid unification. The fact remains that the end result of the democratic process is never entirely predictable. Policies are always subject to revision not only from one administration to the next but within an individual administration in part due to appealing to the public desire. However successful Taiwan's reforms have been, they have done little to assure China that a move towards independence is not around the corner. Taiwan's democracy will remain in jeopardy until the threat from China can be removed. 


\section{References}

Aldrich, John. 1995. Why Parties? The Origin and Transformation of Political Parties in America. Chicago: University of Chicago.

Anderson, Christopher J. 1998. Party Systems, and Satisfaction with Democratic Performance in the New Europe. Political Studies, Vol. 46, No. 3, pp. 572-588

Bartolini, Stefano and Peter Mair, 1990. Identity, Competition, and Electoral Availability: The Stabilization of European Electorates 1885-1985. Cambridge: Cambridge University Press.

Bielasiak, Jack. 2002. The Institutionalization of Electoral and Party Systems in Postcommunist States. Comparative Politics, Vol.34, No. 2, pp.89-210.

Birch, Sarah. 2001. Electoral Systems and Party Systems in Europe East and West. Perspectives on European Politics and Society, Vol.2, No.3, pp.35-77.

Cabestan, Jean-Pierre. 1998. Taiwan's Mainland Policy: Normalization, Yes; Reunification, Later. In Contemporary Taiwan. Edited by David Shambaugh. New York: Oxford University Press.

Carkoglu, Ali. 1998. The Turkish Party System in Transition: Party Performance and Agenda Change. Political Studies. Vol 46, No. 3, pp. 544-571.

Carpenter, Ted Galen 2006. America's Coming War with China; A Collision Course Over Taiwan. Palgrave Macmillan: New York.

Central News Agency. 1997. ROC's UN Bid is Long-Term Goal: Acting Foreign Minister. September 18.

China Post. 2006. More PFP Lawmakers Defect to KMT. January 28.

Christensen, Thomas J. 2001. Posing Problems Without Catching Up: Chinese Rise and Challenges for U.S. Security Policy. International Security, Vol. 25, No.4, pp.5-40.

Comparative Study of Electoral Systems. 2007. [dataset]. (www.cses.org).

Copper, John F. 2003. Taiwan: Nation-State or Province? Boulder: Westview Press.

Copper, John F. 2005. Consolidating Taiwan's Democracy. Lanham, MD: University Press of America.

Cox, Gary W. 1997. Making Votes Count: Strategic Coordination in the World's Electoral Systems Cambridge: Cambridge University.

Cox, Gary W. and Octavio Amorim Neto. 1997. Electoral Institutions, Cleavage Structures, and the Number of Parties. American Journal of Political Science, Vol. 41, pp. 149-174

Dahl, Robert A.1982. Dilemmas of Pluralist Democracy; Autonomy vs. Control. New Haven: Yale University Press.

Downs, Anthony. 1957. Economic Theory of Democracy, New York: Harper and Row.

Duverger, Maurice. 1963. Political Parties. New York: John Wiley and Sons.

Economist. 1999. A Cargo from Taiwan. July 10.

Evans, Geoffrey and Stephen Whitefield. 1998. The Structuring of Political Cleavages in Post-Communist Societies: the Case of the Czech Republic and Slovakia. Political Studies, Vol. 46, pp. 115-139

Garver, John W. 1997. Face Off: China, the United States, and Taiwan's Democratization. University of Washington Press: Seattle.

Geddes, Barbara. 2004. The Development of Party Systems in Latin America. Presented at the Western Political Science Association Meeting.

Hood, Steven J. 1997. The Kuomintang and the Democratization of Taiwan. Boulder, CO: Westview Press. 
Hsieh, John Fuh-Sheng. 2000. East Asian Culture and Democratic Transition, With Special Reference to the Case of Taiwan. Journal of Asian \& African Studies, Vol. 34, No.1, pp. $29-42$

Hsieh, John Fuh-sheng. 2005. Ethnicity, National Identity, and Domestic Politics in Taiwan. Journal of Asian and African Studies, Vol. 40, No. 1-2, pp.13-28.

Huang, Teh-fu. Election and Evolution of Kuomintang. In Taiwan's Electoral Politics and Democratic Transition Edited by Hung-mao Tien. Armonk, NY: M.E. Sharpe.

Huntington, Samuel. 1965. Political Order in Changing Societies. New Haven: Yale.

Kitschelt, Herbert. 1995. The Formation of Party Cleavages in Post-Communist Democracies. Party Politics, Vol 1: pp. 447-472.

Kostelecky, Tomas. 2002. Political Parties After Communism: Developments in East-Central Europe. Baltimore: Johns Hopkins University Press.

Lasater, Martin L. 2000. The Taiwan Conundrum in U.S. China Policy. Westview: Boulder, $\mathrm{CO}$.

Lin, Jih-wen. 2004. Taiwan's Referendum Act and the Stability of the Status Quo. Issues and Studies, Vol. 40, No. 2, pp. 119-153.

Lipset, Seymour M. and Stein Rokkan. 1967. Cleavage Structures, Party Systems, and Voter Alignments: An Introduction. In Party Systems and Voter Alignments: Cross-National Perspectives. Edited by Seymour M. Lipset and Stein Rokkan. New York: Free Press.

Lijphart, Arend, Ronald Rogowski, and Kenneth R. Weaver. 1993. Separation of Powers and Cleavage Management. In Do Institutions Matter? Government Capabilities in the United States and Abroad. Edited by Bert A. Rockman and Kenneth R. Weaver. Washington, DC: Brookings Institution.

MacDonald, Stuart Elaine, Olsa Listhaug, and George Rabinowitz. 1991. Issues and Party Support in Multi-Party Democracies. American Political Science Review, Vol. 85, No.4, pp. 1107-1131.

Mengin, Francoise. 1998. The Foreign Policy of the ROC on Taiwan since 1971: An Overview. In The Republic of China on Taiwan in International Politics. Edited by MarieLuise Nath. Peter Lang Publishing: Berlin.

Miller, Arthur H., Gwyn Erb, William M. Reisinger, and Vicki L. Hesli. 2000. Emerging Party Systems in Post-Soviet Societies: Fact or Fiction? Journal of Politics, Vol. 62, No.2, pp. 455-490.

Mainwaring, Scott. 1993.Presidentialism, Multipartism, and Democracy: The Difficult Combination. Comparative Political Studies, Vol.26, No. 2, pp. 198-228.

Mainwaring, Scott. 1998. Party Systems in the Third Wave. Journal of Democracy, Vol. 9, No.2, pp. 67-81.

Mainwaring, Scott and Timothy Scully (eds.), Building Democratic Institutions: Party Systems in Latin America (Stanford, CA: Stanford Press, 1995).

Nathan, Andrew. 2000. What's Wrong with American Taiwan Policy. The Washington Quarterly, Vol. 23, No. 2, pp. 93-106

Nye, Joseph S. 1998. A Taiwan Deal. Washington Post. March 8.

O'Hanlon, Michael. 2000. Why China Cannot Conquer Taiwan. International Security, Vol. 25, No. 2, pp. 51-86.

Payne, Richard J.and Cassandra R. Veney. 2002. Taiwan and Africa: Taipei's Continuing Search for International Recognition. In Conceptualizing/Reconceptualizing Africa: The Construction of African Historical Identity. Edited by Maghan Keita. Koninklijke Brill Publishers Leiden: Netherlands.

Peterson. M.J. 1997. Recognition of Governments: Legal Doctrine and State Practice, 18151995. St. Martin's Press: New York. 
Pollack, Jonathan D. 1996. China's Taiwan Strategy: A Point of No Return? The China Journal, Vol. 36, pp. 111-16

Powell, G. Bingham. 1982. Contemporary Democracies: Participation, Stability and Violence. Cambridge: Harvard University.

Rae, Douglas W. and Michael Taylor. 1970. The Analysis of Political Cleavages. New Haven, CT. Yale University Press.

Rawnsley, Gary D. 2000. Taiwan's Informal Diplomacy and Propaganda. St. Martin's Press. New York. 2000.

Sartori, Giovanni. 1976. Parties and Party Systems: A Framework for Analysis Cambridge: Cambridge University Press.

Shih, Chih-yu. 2003. Navigating Sovereignty: World Politics Lost in China. Palgrave MacMillan: New York.

Shvetsova, Olga. 1999. A Survey of Post-Communist Electoral Institutions: 1990-1998. Electoral Studies, Vol. 18, No.3, pp.397-409.

Swaine, Michael D. 2004. Trouble in Taiwan. Foreign Affairs, Vol. 83, No. 2, pp. 39-49.

Swaine, Michael and James Mulvenon. 2001. Taiwan's Foreign and Defense Policies: Features and Determinants. Rand Corporation: Santa Monica, CA.

Taipei Times. 2000. Chen Likely to Reject NUC Chair. August 18.

Taiwan Yearbook. Electoral Systems. http://english.www.gov.tw/Yearbook/index.jsp?cate gid $=154 \&$ recordid $=83244$.

Van Kemenade, Willem. 2000. Taiwan, Voting for Trouble? Washington Quarterly, Vol. 23, No. 2, pp. 135-151.

Wachman, Alan M. 1994. Taiwan: National Identity and Democratization. Armonk, NY: M.E. Sharpe, 1994.

Wang, T.Y. 2001. Cross-Strait Relations After the 2000 Election in Taiwan: Changing Tactics in a New Reality. Asian Survey, Vol. 41, No.5, pp. 716-736.

Ware, Alan. 1996. Political Parties and Party Systems. Oxford: Oxford University Press.

Wu, Xinbo.2001. To be an Enlightened Superpower. Washington Quarterly, Vol. 24, No.3, pp. 63-71.

Zielinski, Jakub. 2002. Translating Social Cleavages into Party Systems: The Significance of New Democracies. World Politics, Vol. 54, No. 2: pp. 184-211.

\section{Notes}

${ }^{1}$ Those born on the island but whose families migrated after the Communist takeover of the mainland are still viewed as Mainlanders. In addition, approximately two percent of the population are considered aborigines and are of Malay-Polynesian descent.

${ }^{2}$ Many scholars have noted that the left-right continuum does not travel well to the Taiwan case. The 2004 Comparative Study of Electoral Systems (CSES) poll which asks respondents to place themselves on a left-right scale of 1-10 supports this view. $52.77 \%$ of respondents stated they did not know, while $23.97 \%$ chose the middle (5). My contention is only that the issue of independenceunification continuum has a similar end result..

${ }^{3}$ For the sake of clarity, respondents in favor of unification as soon as possible and the status quo now/unification later were combined as were similar independence supporters.

${ }^{4}$ This move towards the center can also be viewed in PFP defections to the KMT. China Post. "More PFP Lawmakers Defect to KMT.” January 28, 2006.

${ }^{5}$ Coalition support was determined by adding the percentage of respondents indicating support for an individual party, a coalition in general, or multiple members within a coalition. Those indicating sup- 
port for parties in different coalitions (i.e. DPP and KMT) were not included. 2004 Taiwan National Security Survey.

${ }^{6}$ Geddes and Aldrich seem to acknowledge this possibility. Barbara Geddes. "The Development of Party Systems in Latin America." Presented at the Western Political Science Association Meeting. March 2004; John Aldrich. Why Parties? The Origin and Transformation of Political Parties in America. Chicago: University of Chicago. 1995.

${ }^{7}$ The Pedersen's Index is computed by adding the net difference in percentage of votes by each party from one election to the next then divided by two.

${ }^{8}$ Since several parties only appeared in one of the elections, their vote totals were conflated with the percentage for independent candidates. The KMT and DPP comprised $83.3 \%$ of votes in 1992 . The KMT, DPP, and NP comprised $92.3 \%$ o and $83.1 \%$ of votes in 1995 and 1998 respectively, whereas they along with the PFP and NP comprised $91.7 \%$ of votes in 2001 and $90.3 \%$ in 2004. Central Election Commission Republic of China (Taiwan).

${ }^{9}$ The growing bipartisan support for Taiwan is evident in the size of the Congressional and Senate Taiwan Caucuses. The Congressional Taiwan Caucus, founded in April of 2002 and headed by two Democrats and two Republicans, originally had 85 members. By 2007 membership had almost doubled to 155 members, with nearly half being Democrats. The Senate Taiwan Caucus presently has a lower ratio of Democrats (9 out of 25 in 2007), but does suggest support for Taiwan is no longer as partisan as in the past.

${ }^{10}$ Bhutan is the only country with no formal relations with either side but has been in negotiations with the PRC since 1984 regarding their shared border and has consistently supported Beijing's position on Taiwan.

${ }^{11}$ For example, in 1999 the Prime Minister of Papua New Guinea announced his country would establish diplomatic relations with the ROC, allegedly in exchange for a $\$ 2.5$ billion loan. Days later, amid domestic backlash and pressure from the PRC and Australia, the Prime Minister resigned and the country retained relations with the mainland The Economist. "A Cargo from Taiwan." July 10, 1999: p. 38. 